\title{
VISUALIZING THE LIGHTNING FLASHES OVER THE REPUBLIC OF AZERBAIJAN BY ANALYZING THE LIGHTNING IMAGING SENSOR DATA
}

\author{
Mammadov R. ${ }^{1}$, Rasouli A.A. ${ }^{2}$, Safarov S. ${ }^{1}$, Safarov E. ${ }^{1}$ \\ ${ }^{1}$ Institute of Geography, Azerbaijan National Academy of Sciences, Baku, Azerbaijan \\ 115, H.Javid ave., Baku, Azerbaijan, AZ1143 \\ ${ }^{2}$ Department of Environmental Sciences, Macquarie University, Sydney, Australia \\ Level 4, 12 Wally's Walk, Macquarie University, \\ North Ryde, Sydney, Australia: aarasuly@yahoo.com
}

Keywords: Azerbaijan, lightning, temporal-spatial patterns, lightning hazard map
Summary. Available lightning data from the Lightning Imaging Sensor (LIS) was analyzed to determine the temporal variation and spatial distribution of lightning strikes (flashes) over the Republic of Azerbaijan. Each detectable flash is considered an atmospheric event. Nearly about 2074 flashes for the warm and cold months from 2017 to 2020 were combined to form four years "lightning dataset" of a thundery-warned region, with its scattered cities and districts with a population of nearly 10 million. A "GIS-oriented procedure" was intently applied by importing all lightning observations to create appropriate distinct digital layers needed for the subsequent temporal-spatial analysis. A range of analytic tools mainly for analyzing and mapping existing spatial patterns among data layers have been applied. The resulting spatial indexes have established various temporal-spatial patterns, indicating clusters of lightning frequency and associate values, statistically significant inside of Azerbaijan lands. Lastly, in recognizing the most flash risk areas, a combined fuzzy membership operator was applied to the raster database, based on Kendal Density output layers.

The final results indicated that more than $99 \%$ of the flashes occur from April to September with a single peak in June and substantial lightning activity takes place in summer months, indicating a prominent diurnal afternoon peak, in the region. Also, spatial patterns illustrated that the most frequent and energetic lightning events, with the highest radiance values and longest durations, happen over the western and northern parts of the country, mainly over the elevated areas of Karabakh and Caucuses mountains, indicating the highest lightning strike risky areas.

(c) 2021 Earth Science Division, Azerbaijan National Academy of Sciences. All rights reserved.

\section{Introduction}

Lightning is the occurrence of a natural electrical discharge of very short-duration and high voltage between a cloud and the ground or within a cloud, as a common atmospheric electricity phenomenon (Mackerras et al., 1998; Williams, 2005). The American Meteorological Society defines lightning as "the series of electrical processes taking place continuously by which charge is transferred along discharge channels between electric charge centers of opposite sign" (Peterson, 2016). Normally, violent and sudden electrostatic discharge generates a bright flash and thunder (Koehler, 2020). Scientists believe that it starts when an electric current forms in a cloud when the ground is hot and heats the air directly above it (Albrecht et al., 2016). Flashes are produced mainly from cumulonimbus clouds, which form through four mechanisms: buoyant warm air rising due to intense surface heating, strong heating contrast between surfaces, frontal lifting, or by the uplift of air parcels due to orographic lifting (Changery, 1981). All of these processes may trigger convection and, hence, a lightning activity which originates around 3-4 km above sea level and is effectively caused by a charge separation that takes place within the negatively charged reservoir of the cloud and the positive electric field of the ground surface (Cooray, 2015). The resulting discharge is negative, positive, or cloud-to-cloud stroke (Rakov, 2016).

Information concerning the characteristics of flashes in different geographical regions is of interest and augment research on the interaction between 
the radiative properties of the surface and the atmosphere (Bruning and Thomas, 2015). Lightning activities have been detected by traditional classic techniques and space-borne observation methods (Wanke, 2014). Lightning Image System (LIS) as one of the recent methods is invented to observe and measure different parameters of the lightning action (NASA EOSDIS..., 2013). The LIS is a NASA Earth Observing System (EOS) instrument on the Tropical Rainfall Measuring Mission (TRMM) platform designed to acquire and investigate the distribution and variability of total lightning observation (Christian et al., 1992).Understanding the mechanism and characteristics of the lightning reader may refer to basic researches (Rakov, 2016; Bitzer, 2017).

Previous studies have shown that the thunderstorms and associated phenomenon of lightning are very important in Azerbaijan (Safarov and Mekhtieva, 2017). Despite considerable researches done, there is yet very little understanding of the spatial distribution of lightning-related features such as flash frequency, radiance, and duration values. Also, it seems that the relationship between lightning strikes and surface characteristics of elevation, vegetation type, and other surface in-homogeneities, such as fire scars, burned areas are not being precisely under accurate investigations inside Azerbaijan. Meanwhile, according to a few investigations, it was found that lightning activities appear to be increasing during recent years (Gashimov et al., 2020). Flashes of lightning could result in several widespread severe thunderstorms around the country by introducing infrequent torrential precipitation, super hailstones, high-speed gustywinds. These may cause extensive damages to the country's natural environment and the city's infrastructures. Accordingly, in the present study in the first stage, the authors attempt to visualize tempospatial distributions of lightning flashes, on the country scale based on the available LIS database.

\section{Study Area}

The LIS data was analyzed to make this paper more sensible in the largest and most populous country in the Southern Caucasus. Geographically the Republic of Azerbaijan is dominated by the Caspian Sea forming its eastern border, the Greater Caucasus Mountain range to the north, the Lesser Caucasus in the southwest, the Talish Mountains to the south, and the extensive Aran lowlands in the center of the country (Mammadov and Budagov, 1996). Azerbaijan lands are dominated by the river basins of the Kura and the Araz rivers as the most watery tributary. Nearly about 60 percent of the country consists of mountains and their foothills; the elevation changes over a relatively short distance from lowlands to highlands (Fig. 1). The climate varies from dry and hot in the central and eastern parts of the country to the humid climate types in the south-east. At higher elevations of the Caucasus and Karabakh mountains cold and wet climate is expected. At the same time, the temperate climate along the shores of the Caspian Sea is dominated. In such diverse climates, the possibility of initiating thunderstorms accompanied by flashes of lightning is very likely particularly during hot and wet months of the year (Safarov, 2007).

\section{Data Analysed}

In the detection of geographic distributions of flashes on a regional-scale, LIS observation was obtained from the Earth data - Global Hydrology Resource Center and then a database has been created, with high temporal and spatial accuracy (Blakeslee, 1998). As of 2017, the LIS-orbit coverage was extended to the higher latitudes, and flash data are currently being accessed for later analysis, as it has been done in current research. The LIS data consists of information on the date, time, duration, location, number of events and radiance values (Cecil et al., 2014). To compare the existing temporal-spatial changes, the vector and raster layers were clipped, as much as its major cities, districts, and a Digital Elevation Model (DEM) inside a GIS setting (Fig. 1).

Accordingly, the cold and warm months dataset were incorporated into a database set to allow for the exploration of flashes with its temporal-spatial characteristics, such as the number of flashes, flash radiance, and durations for the different time-scales using ArcMap version 10.5 (Understanding Spatial Statistics in ArcGIS, 2006). From 2017 to 2020, entirely, 2074 flashes precisely were recorded over Azerbaijan during time. Exactly 20 flashes were observed (less than 1 percent of total flashes) in the study area during the cold months, which were not analyzed due to statistical insufficiency.

\section{Methods Applied}

A few primary to advance techniques were stepwise applied to the created datasets according to the current study aims. To manage different sorts of data layers, sequences of entering, editing, databasecreation, querying, analyzing, modeling and mapping processes have been progressively introduced (Gelfand, 2010).

First, a definition query was applied to explore LIS tempo-spatial occurrences on the features' attributes. For some SQL-based functions it is possible to check all datasets and look at the relations of LIS types in the attribute tables (Rasouli et al., 2015). In the second step, a Nearest Neighbor Index (NNI), as a spatial analyst tool, was applied (Ord and Getis, 1995) to illustrate probable spatial patterns in the data. The null hypothesis for this kind of analysis states 
that there is no pattern, i.e. the LIS expected pattern is one of hypothetical random chance (Haining, 2010). The $\mathrm{Z}$ score, which is a measure of standard deviation and a test of statistical significance that helps decide whether or not to reject the null hypothesis, was calculated for all sorts of analyses (Fischer and Getis, 2010). To understand how to calculate the coefficients of the NNI functions note the ESRI guide (How Fuzzy Overlay works, 2020).

Then, for generalizing the localized incident geographic locations of lightning occurrence to an entire area a Kernel Density Interpolation estimator was introduced. A Kernel density tool calculates the density of point features such as lightning occurrence locations in a search radius around all similar features (Kelsall and Diggle, 1995). More details on the subject could be found in the relevant sources. Lastly, a combined fuzzy membership function was applied to the rasters data together, based on lightning extracted parameters such as flash density, flash radiance and flash duration layers (Zimmermann, 2001). The Fuzzy Overlay tool allows the analysis of the possibility of a phenomenon (for instance, flash duration) belonging to multiple sets in a multi-criteria overlay analysis. Not only does fuzzy overlay determine what sets the phenomenon is possibly a member of, but it also analyzes the relationships between the members of the multiple sets. Ap- plying a fuzzy overlay method made possible to identify high-risk areas of lightning by combining and equally-weighted raster layers distribution (How Fuzzy Overlay works, 2020). All the abovementioned spatial analyses were settled and executed in a Model Builder framework, automating the standard ArcGIS software (Scott and Janikas, 2010).

\section{Results and Discussion}

\section{a) Temporal-Spatial Variations}

Inside the Azerbaijan lands, the total number of flashes (2017-2020) was described for different time-scale periods. Fig. 2a shows the yearly counts of flashes inside the Azerbaijan border for each year. Remarkable inter-annual variations are not obvious in the number of flashes, whereas the highest lightning activity is observed in 2018 and the lowest in 2017 inside the study area. Areas with a higher number of flashes each year are red-violet; areas with a lower number of flashes are clear. Flashes are most frequent over the western and northern parts of Azerbaijan than over the lowlands and eastern parts. Lightning seems to happen more often closer to the elevated regions. On a seasonal basis, there is a considerable contrast across the country by peak densities occurring in spring wet months and then in the summer warm months, as the total number of flashes for the study period are presented (Fig. 2b).

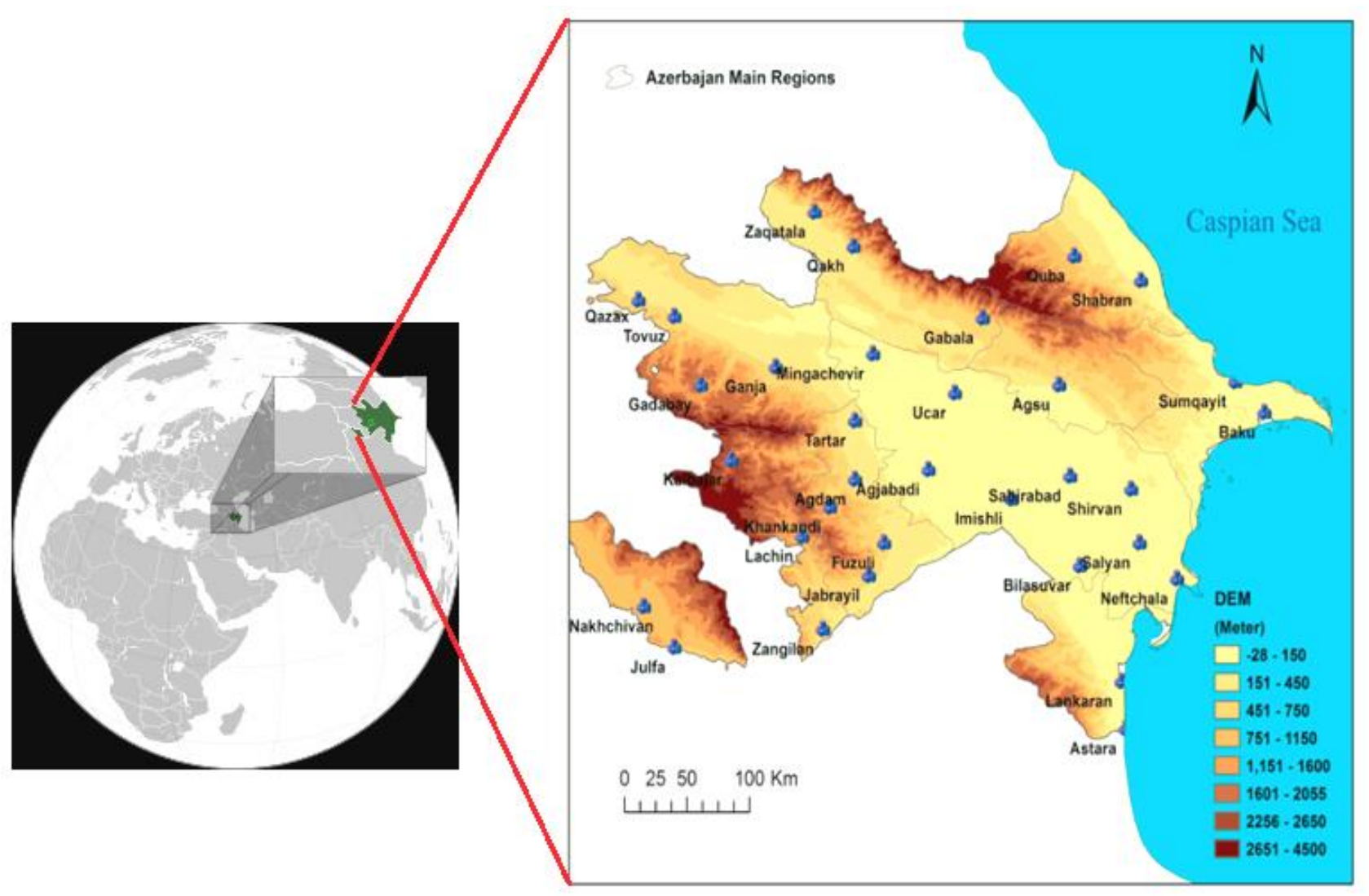

Fig. 1. The location map of the Republic of Azerbaijan, including main cities, overlaid on a DEM map 

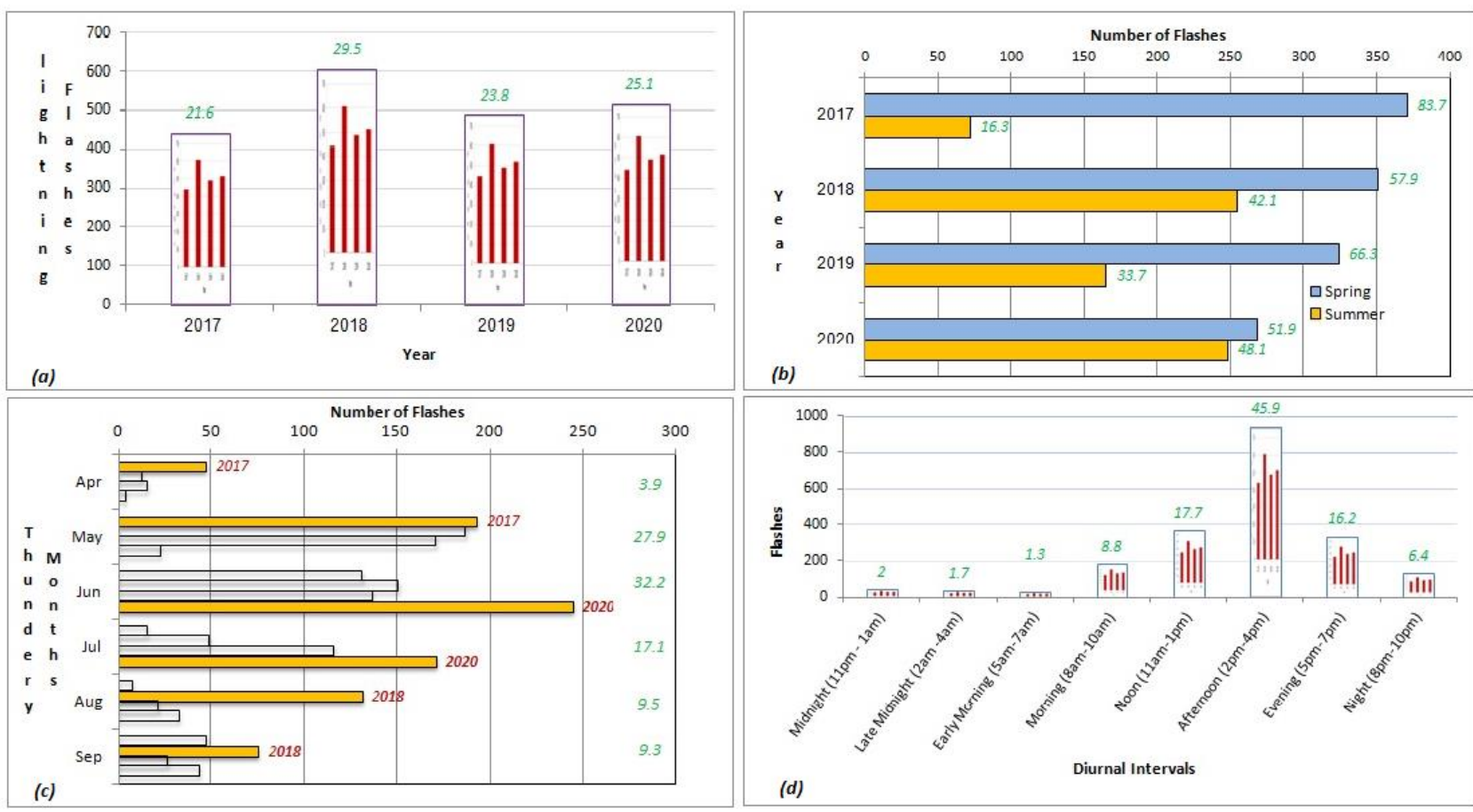

Fig. 2. Lightning flashes temporal variations for yearly (a), seasonal (b), monthly (c), and diurnal time-scales (d) inside Azerbaijan; percentages are indicated in green figures

During the wet-warm seasons, flashes are not uniformly distributed across Azerbaijan, though the lowlands and eastern regions have less frequent flashes (Fig. 3).

Time-scales on the monthly and diurnal distributions of flashes are illustrated in Figs. 2c,d respectively. The greatest number of flashes were observed during June, May, and July with 32.2, 27.9 and $17.3 \%$ respectively (Fig. 2c). Note that once again an asymmetric spatial distribution is recognizable during wet-warm months, particularly in spring. Fig. $2 \mathrm{~d}$ shows the diurnal variation of lightning activity in percentage with one peak at 2-4 pm (45.9\%) and two secondary peaks at $11 \mathrm{am}-1 \mathrm{pm}(17.7 \%)$ and at 5-7 pm $(16.2 \%)$. The lightning activity is strong in the afternoons and weak during mid-nights and early mornings (nearly about 2\%). Lightning flashes (for day-time and night-time) are characterized by remarkably large inter-diurnal variability and abrupt changes. The highest number of flashes was observed at about 942 in the afternoon, whereas the lowest number 26 was reported for the early morning. Fig. 4a,b highlights warm months and diurnal temporal-spatial variation of lightning flashes over Azerbaijan.

\section{b) Spatial Patterns}

The results of the spatial analysis are given according to the main aims of the study by implementing a few appropriate techniques. The NNI appears as 0.99 which is indicative of a significant clustering pattern. As it indicates there is less than 1 percent likelihood that this clustered pattern of flashes distribution could be the result of random chance. To test the significance, the value of $\mathrm{Z}$ is compared with a normal distribution, as the NNI and standard normal deviates $(\mathrm{Z}$ score $=-27.82)$ of the lightning dataset indicate that the flashes exhibit a clear significant degree of clustering inside Azerbaijan statistically. Then, a Kernel Density function was applied to the spring season and afternoon pick-time data with four lightning elements to visualize the spatial distribution of flashes over Azerbaijan. This includes the number of flashes (a), the flash frequency (b), flash radiance values (c), and flash duration (d), by weighting the attribute fields to their geographic locations on a nominal scale (see fig. 5, 6).

Related raster-based spring season distribution patterns indicate that the highest lightning occurrence is seen in the western and northern parts of the country over the higher elevations and lower values - in the middle and eastern parts of the study area (Fig. 5a,b). By careful inspecting of lightning distribution patterns, two more incidence causeways could be visually recognized; one passage starts from the north-west curved over the Caucasus Mountains, crossing to the south-east. Another track tops some parts of the Karabakh Mountains. In contrast, it seems that the Caspian Sea coastal areas experience less lightning activities, except for some small parts of the Lankaran District. There, particularly over the Nakhchivan District, would appear as several small-scaled pockets with relatively more flashes during the time considered (Fig. 5 c,d). 


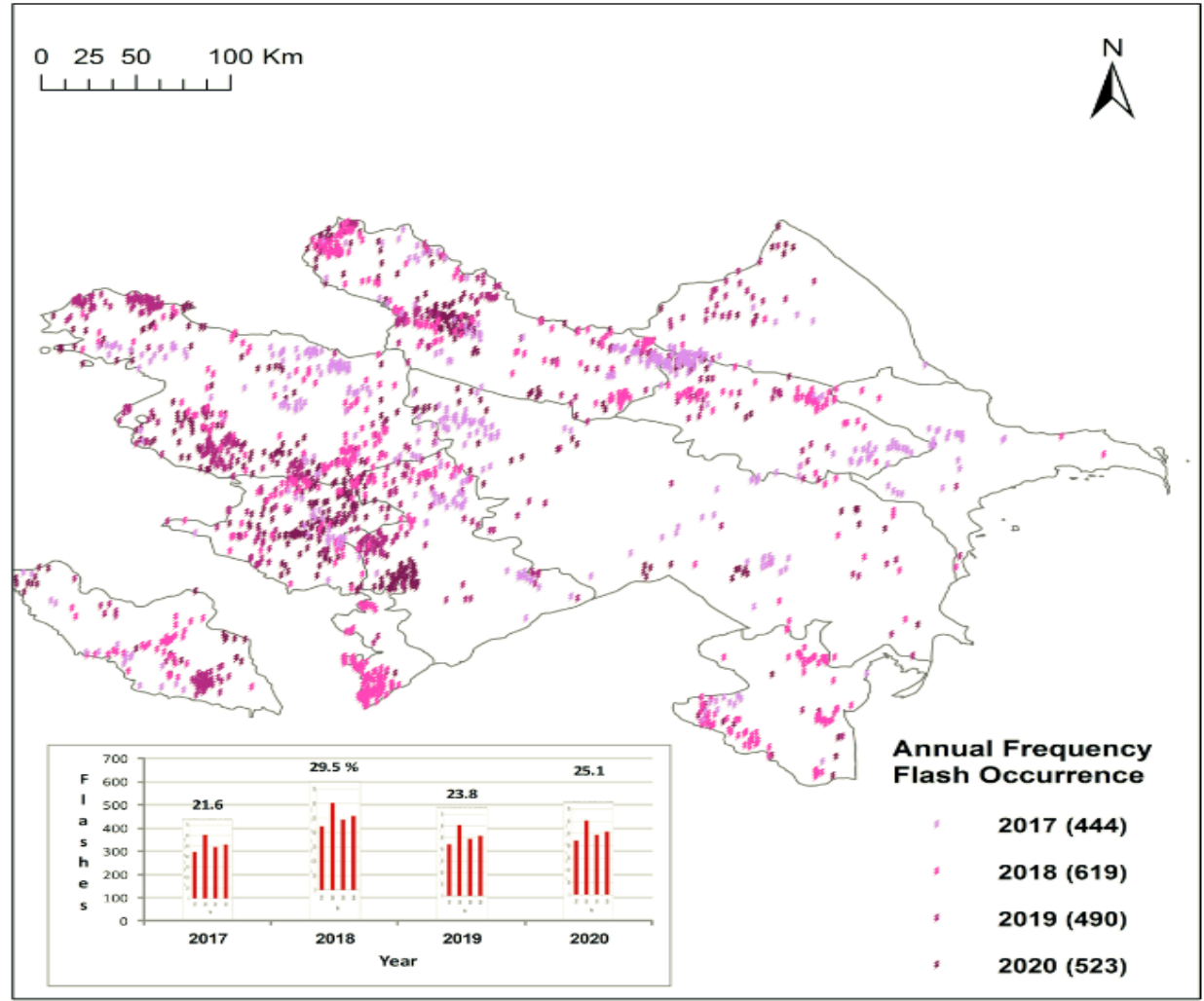

a

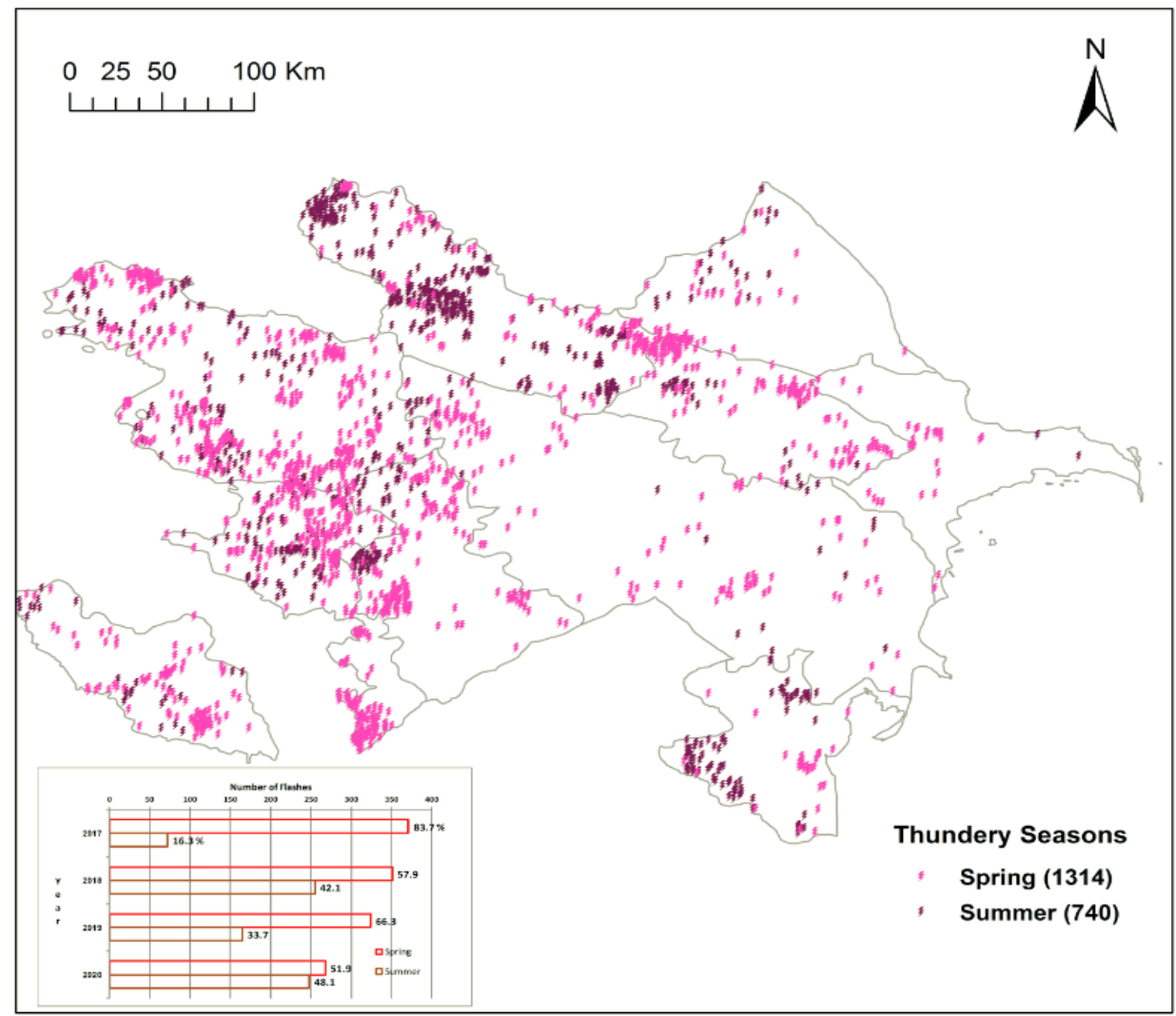

b

Fig. 3. Yearly (a) and thundery seasons (b) spatial distribution of lightning flashes inside Azerbaijan. The percentages of temporal distributionsare shown by linked histograms 


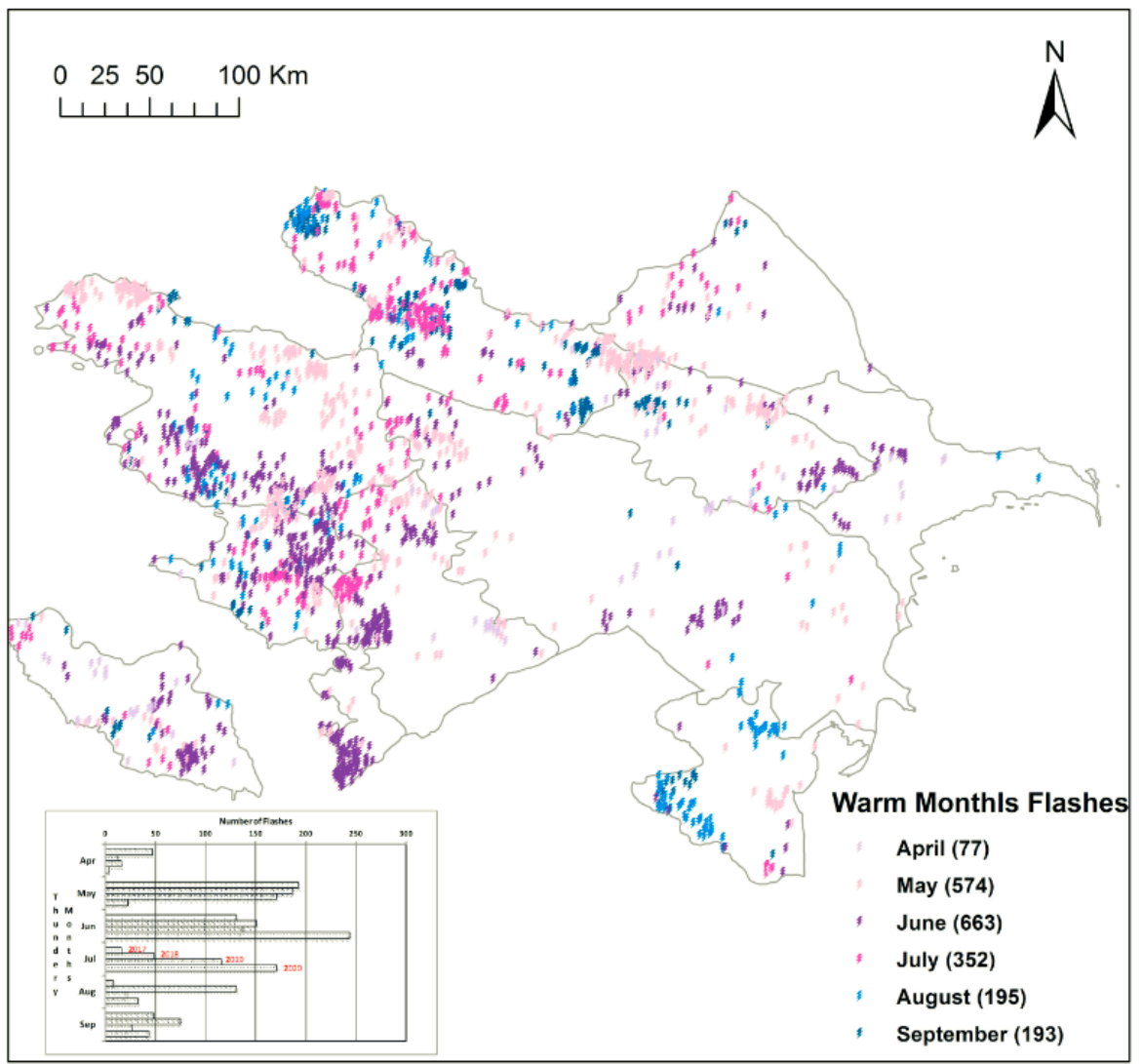

a

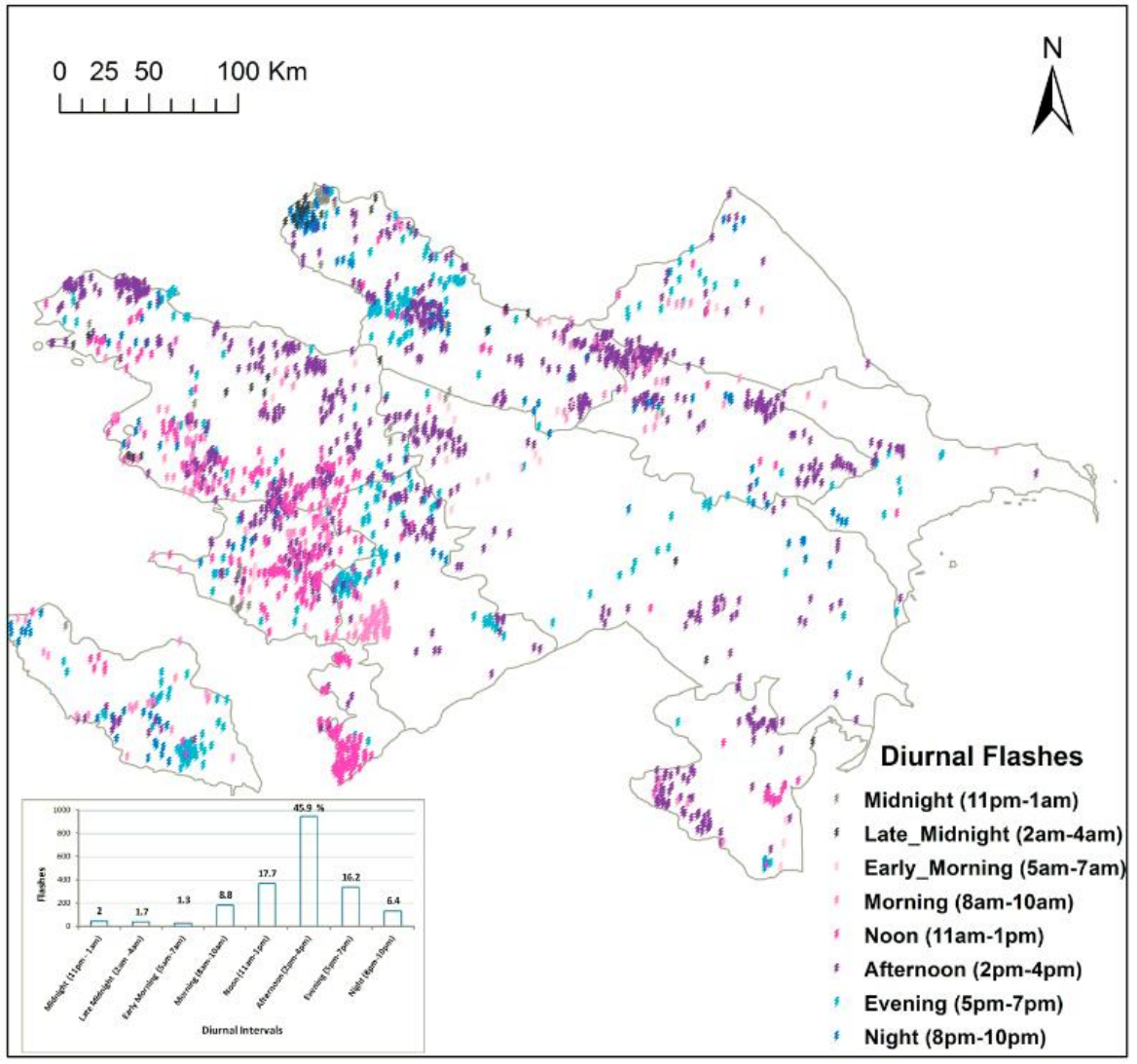

b

Fig. 4. Warm months (a) and diurnal (b) variation of lightning flashes over Azerbaijan. The percentages of temporal distributions are shown by linked histograms 


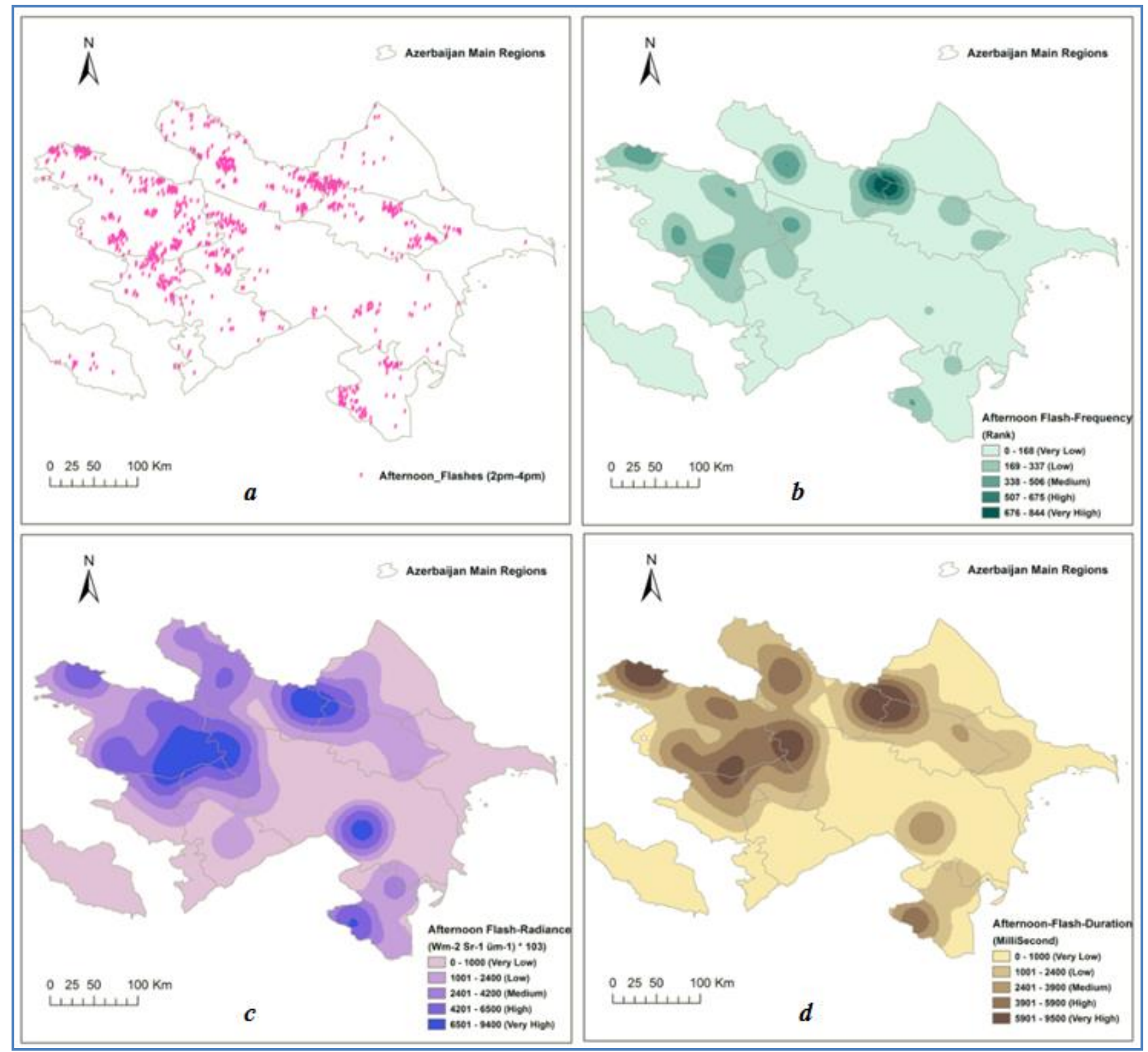

Fig. 5. The Kernel Density outputs for lightning elements as a, b, c \& $\mathbf{d}$ indicating flash occurrence, frequency, radiance and duration respectively during the afternoon pick-time $(2-4 \mathrm{pm})$

Once again, a Kernal Density was applied to map June and afternoon time-period (2 pm-4 pm) flash data (Fig. 6). It seems that the lightning magnitudes; the number of flashes (a) flash frequency (b), flash radiance values (c) and flash duration (d) appear similar to warm months distributions, at the same time with some differences. For instance, during June, the month with the highest number of flashes, the spatial distribution changes somewhat.

The highest number of flashes are detected in the Karabakh region, with low density and weaker flash duration around the region. As expected, the peak hour for flashes country-wide is between 2-4 pm. Although the general pattern of the afternoon lightning distribution (Fig. 5) is similar to the warm months, the study area receives fewer flashes with weaker flash radiances. To compare the final results, the flashes properties such as frequency, radi- ance and duration statistics are given in Table 1 for different temporal-scales inside the study area. It is evident from the statistics given in Table 1, the greatest number of flashes was observed over Azerbaijan during the warm months in the spring, in June, and the afternoon period (2-4 pm). Nevertheless, the uppermost values of flash radiance and duration statistics may differ to some degree (notice inside the brackets in Table 1).

\section{c) Lightning Hazard Map}

Fig. 7 visualizes the spatial changes in lightning risks over the study area, by applying a fuzzy overlay function. "The lightning hazard map" highlights the local threat of lightning in Azerbaijan by scaling the lightning frequency, radiance, and duration flash values related to their attribute fields' and geographic locations (Yair et al., 2014). 
Geography

Total number of flashes derived from LIS-dataset and flash properties for dissimilar temporal scales

\begin{tabular}{|c|c|c|c|c|c|c|c|}
\hline $\begin{array}{l}\text { Temporal Scale } \\
\text { Pick-Periods }\end{array}$ & \begin{tabular}{|c|} 
Flash Frequency \\
Number $(\%)$
\end{tabular} & \multicolumn{3}{|c|}{$\begin{array}{c}\text { Flash Radiance } \\
\left(\mathrm{Wm}-2 \mathrm{Sr}-1 \text { üm-1) } * \mathbf{1 0}^{3}\right.\end{array}$} & \multicolumn{3}{|c|}{$\begin{array}{l}\text { Flash Duration } \\
\text { (MilliSecond) }\end{array}$} \\
\hline Statistics & Count & Min & Mean & Max & Min & Mean & Max \\
\hline Warm Months (Apr-Sep) & $2054(99)$ & 4 & 354.9 & $\begin{array}{c}97134 \\
\text { (13Jun 2020) }\end{array}$ & 0.1 & 206.8 & $\begin{array}{c}2716 \\
\text { (28 May 2019) }\end{array}$ \\
\hline Spring (Apr-Jun) & $1313(64)$ & 4 & 429.1 & $\begin{array}{c}97134 \\
\text { (13Jun 2020) }\end{array}$ & 0.1 & 221.8 & $\begin{array}{c}2716 \\
\text { (28 May 2019) }\end{array}$ \\
\hline Summer (Jul-Sep) & $741(36)$ & 4 & 223.3 & $\begin{array}{c}3528 \\
(18 J u l 2018)\end{array}$ & 0.1 & 180.2 & $\begin{array}{c}1321 \\
(23 \text { Aug 2020) }\end{array}$ \\
\hline June & $663(32)$ & 4 & 527.7 & $\begin{array}{c}97134 \\
\text { (13Jun 2020) }\end{array}$ & 0.1 & 203.6 & $\begin{array}{c}1716 \\
\text { (05 Jun2018) }\end{array}$ \\
\hline Afternoon (2pm-4pm) & $942(46)$ & 4 & 232.5 & $\begin{array}{c}4084 \\
\text { (06Jun 2020) }\end{array}$ & 0.1 & 201.2 & $\begin{array}{c}2716 \\
\text { (28May 2019) }\end{array}$ \\
\hline Autumn (Oct-Dec) & $17(0.8)$ & 5 & 191.3 & $\begin{array}{c}948 \\
(03 \text { Oct } 2020)\end{array}$ & 0.1 & 181.1 & $\begin{array}{c}608 \\
(030 c t 2020)\end{array}$ \\
\hline Winter (Jan-Mar) & $3((0.2)$ & 4.4 & 1118.7 & $\begin{array}{c}3011 \\
(30 \mathrm{Mar} 2020)\end{array}$ & 0.1 & 406 & $\begin{array}{c}973 \\
(30 \mathrm{Mar} 2020)\end{array}$ \\
\hline
\end{tabular}
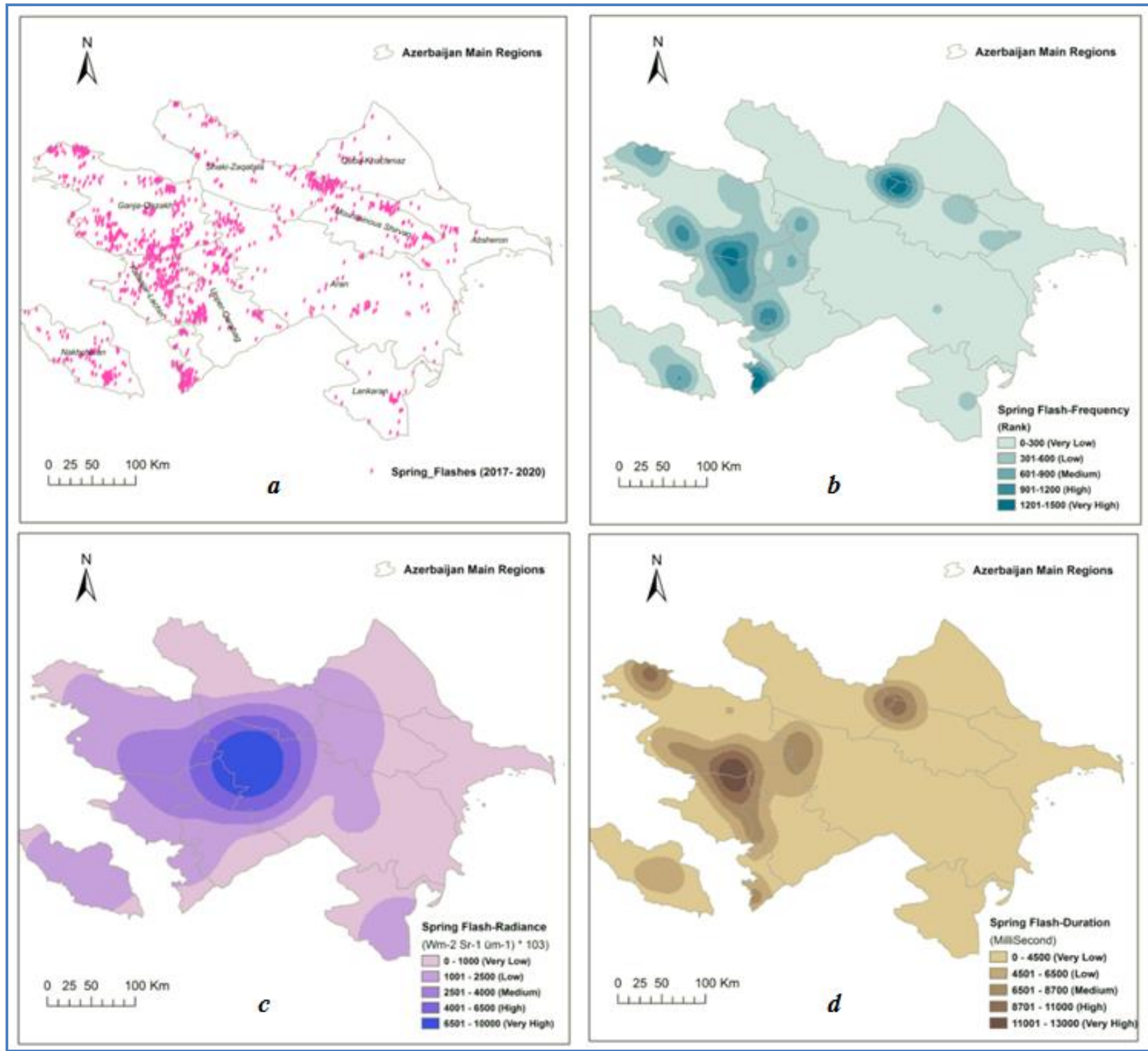

Fig. 6. The Kernel Density outputs for lightning elements as a, b, $\mathbf{c} \& \mathbf{d}$ indicating flash occurrence, frequency, radiance and duration respectively during the spring season 


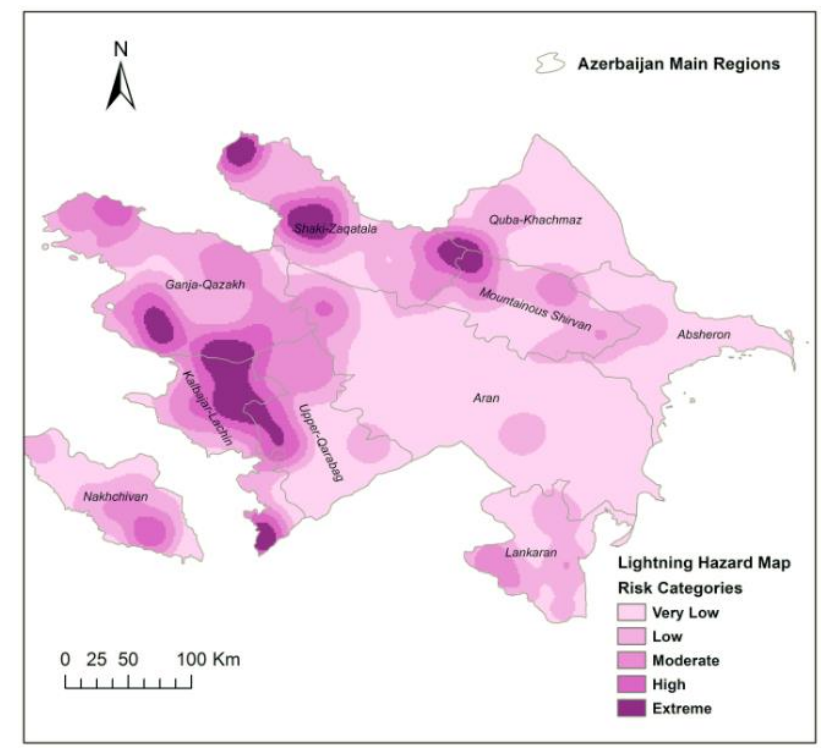

Fig. 7. "The lightning hazard map" highlights the nation-wide threat of flashes in Azerbaijan

As it is shown in Fig. 7, the "lightning hazard map" delineates the local threat of lightning for all districts in Azerbaijan. With emphasis, areas located around the Caucuses Mountains such as Balaken, Zagatala, Gazakh, Gabala, Agstafa, Ismayilli, and Sheki have the highest risk from lightning. Similarly, Gadabay, Lachin, Dashkasan, Kalbajar, Shusha, Khojaly and Zangilan districts, largely located near or around the Karabakh Mountains, are exposed to the extreme or high risks from lightning. With a high probability, during the thunderstorm activity, many Azerbaijanians may be struck by lightning activities and they may be killed or suffer from permanent neurological disabilities. In contrast, other districts located in lowlands or the eastern parts of the country, with emphasis on Sumgayit, Baku, Khizi, Shabran, Neftchala and Salyan may expose to the lowest risks from flashes of lightning during the year. If we have trustable precise temporal-spatial information on the lightning occurrences throughout the country, most targeted could be saved (Safarov, 2008).

The current paper results indicate that most of the lightning flashes occur during the spring and summer months, mostly during the afternoon times. Lightning occurs more often in these timescales because there to be high amounts of moisture in the air along with warm rising air. There must be instability in the atmosphere, particularly during the warmer months, when the humidity is much higher. Weather systems, such as cold airmasses, the Kara and Scandinavian arctic anticyclones, the temperate Siberian anticyclones, and the maritime Azores, may affect the lightning activity in the region (Mammadov et al., 2009). The air masses may enter the country in different ways thanks to its varied geography. With a higher chance, during warm and humid months, for instance, in June, the Azerbaijan climate could be influenced by the humid subtropical air masses, or even a cold front, when you may expect hot weather and thereafter thunderstorm events from time to time. Therefore, thunderstorms and lightning are most common during convective periods, when there is a strong influence from the wet weather systems; those have a significant role in distributing moisture throughout the region.

Furthermore, the temporal-spatial analysis indicated that the highest occurrence of lightning activities is confined to the higher elevated parts of the Karabakh region and Caucuses Mountains while the Kura-Aras lowlands and the Caspian Sea coastal areas have the lowest lightning flash occurrences. There are also clear differences and meaningful spatial polarization of lightning activities during the west and north-west of the country, particularly during the wet and warm seasons. One main outcome of the study was an up-to-date knowledge of the LIS-database about regional lightning distributions by applying a "GIS oriented procedure". As the NNI indicates, there are some significant clustering patterns, as there is less than 1 percent likelihood that this clustered pattern of lightning distribution could be the result of random chance. Moreover, based on the density maps, various calculations regarding the coherence between lightning activity and altitude could be made. Thereby, high positive correlations could be seen in the districts located around the Caucasus Mountains and the Karabakh region. In general, the correlations strongly depended on the relief of the considered regions. Areas with a quite low altitude, such as the lowlands in the middle of the country and the Caspian Sea coastal areas, show very low positive correlations, whereas mountainous regions tended to very high positive correlations.

The assumption of high lightning activities at convex mountain tops or ridges could be highlighted in the coming investigations. Additionally, due to the emergence of the climate change signatures around Azerbaijan, the phenomena related to severe thunderstorms have to be considered at local, regional, and nationwide levels (Second national communication..., 2010; Safarov et al., 2017). There is a certain need that among the other thunderstorms phenomenon such as destructive hail events and intensive flash-flooding rainfalls should be extensively considered by researchers and decision-makers (Rasouli and Cheung, 2013; Mammadov, 2015). 


\section{Conclusion}

This initial study brings out the following conclusions:

$\checkmark$ The lightning activity should be seen as the output of thunderstorm activity that could strike far more frequently under the Azerbaijan climatic circumstances, particularly over the Caucuses and Karabakh mountains and less nearby the Caspian Sea and lowlands.

$\checkmark$ There are many pieces of evidence showing meaningful differences in the frequency of flashes during the last four years (2017-2020). They are much active during wet and warm months, particularly during spring and early afternoons.

$\checkmark$ Spatial models showed some differences, at least on a regional scale. Nevertheless, these models can reveal the interaction between the strong influence of humid air masses and topographic features of the terrain, which affect the control of extensive severe thunderstorm processes, which, in turn, can be attributed to the same category of active synoptic weather system.

$\checkmark$ In most cases, on the ground, such storms have catastrophic and significant expensively impacts upon the natural environment and social community in those districts, mostly located over highelevated areas in the current circumstances.

$\checkmark$ If the consensus of climate change is accepted, then meteorologists and climatologists have to

\section{REFERENCES}

Albrecht R.I., Goodman S.J., Buechler D.E., Blakeslee R.J., Christian H.J. Where are the lightning hotspots on Earth? Bulletin of the American Meteorological Society, Vol. 97, No.11, 2016, pp. 2051-2068.

Bitzer P.M. Global distribution and properties of continuing current in lightning. Journal of Geophysical Research: Atmospheres, Vol. 122, No. 2, 2017, pp. 1033-1041.

Blakeslee R.J. Lightning Imaging Sensor (LIS) on TRMM science data Dataset available online from the NASA global hydrology center DAAC. Huntsville, AL 10.5067/LIS/LIS/ DATA, 1998, $201 \mathrm{p}$.

Bruning E.C., Thomas R.J. Lightning channel length and flash energy determined from moments of the flash area distribution. Journal of Geophysical Research: Atmospheres, Vol. 120, No. 17, 2015, pp. 8925-8940.

Cecil D.J., Buechler D.E., Blakeslee R.J. Gridded lightning climatology from TRMM-LIS and OTD: Dataset description. Atmospheric Research, Vol. 135-136, 2014, pp. 404-414.

Changery M.J. National thunderstorm frequencies for the Contiguous United States. NUREG/CR, National Climatic Center, National Oceanic and Atmospheric Administration, Vol. 2252, 1981, $57 \mathrm{p}$.

Christian H.J., Blakeslee R.J., Goodman S.J. Lightning Imaging Sensor (LIS) for the Earth-observing system. NASA TM4350, available from the National Technical Information Service, Springfield, VA. 22161-2171, 1992, 36 p.

Cooray V. An introduction to lightning. Springer. 2015, 262 p. pay much attention to the advanced methods of lightning observation. These may lead to intense thundery rainfalls leading to flash flooding, destructive hail events, hurried winds, and suspect tornadoes by estimating the heat energy available to "fuel" severe thunderstorm clouds.

$\checkmark$ By year, in Azerbaijan, several deaths resulting from lightning activities are reported. They could affect telecommunications, power utilities, aviation, and the insurance industry, among other socio-economic impacts. Therefore, quantification and mapping of lightning activity have become important areas of research throughout the country that should use in risk management analysis, lightning protection analysis, and township planning projects.

\section{Acknowledgment:}

The data was provided by the NASA Lightning Imaging Sensor (LIS) instrument team and the LIS data center via the Global Hydrology Resource site. We would like to appreciate many scientists who made such valuable data achievable. We like to appreciate the head and academics from the Department of Environmental Sciences, the University of Macquarie in Australia for their great scientific assistants. Spatial thanks go to our kind colleagues from the Institute of Geography of the Azerbaijan National Academy of Sciences, who sincerely assisted us in various scientific ways.

\section{LITERATURE}

Albrecht R.I., Goodman S.J., Buechler D.E., Blakeslee R.J., Christian H.J. Where are the lightning hotspots on Earth? Bulletin of the American Meteorological Society, Vol. 97, No.11, 2016, pp. 2051-2068.

Bitzer P.M. Global distribution and properties of continuing current in lightning. Journal of Geophysical Research: Atmospheres, Vol. 122, No. 2, 2017, pp. 1033-1041.

Blakeslee R.J. Lightning Imaging Sensor (LIS) on TRMM science data Dataset available online from the NASA global hydrology center DAAC. Huntsville, AL 10.5067/LIS/LIS/ DATA, 1998, $201 \mathrm{p}$.

Bruning E.C., Thomas R.J. Lightning channel length and flash energy determined from moments of the flash area distribution. Journal of Geophysical Research: Atmospheres, Vol. 120, No. 17, 2015, pp. 8925-8940.

Cecil D.J., Buechler D.E., Blakeslee R.J. Gridded lightning climatology from TRMM-LIS and OTD: Dataset description. Atmospheric Research, Vol. 135-136, 2014, pp. 404-414.

Changery M.J. National thunderstorm frequencies for the Contiguous United States. NUREG/CR, National Climatic Center, National Oceanic and Atmospheric Administration, Vol. 2252, 1981, 57 p.

Christian H.J., Blakeslee R.J., Goodman S.J. Lightning Imaging Sensor (LIS) for the Earth-observing system. NASA TM4350, available from the National Technical Information Service, Springfield, VA. 22161-2171, 1992, 36 p.

Cooray V. An introduction to lightning. Springer. 2015, 262 p. 
Fischer M.M., Getis A. Handbook of applied spatial analysis software, tools, methods and applications. Springer-Verlag Berlin Heidelberg. 2010, 805 p.

Gashimov A.M., Khidirov F.L. Babayeva A.R. Strength of the lightning activity in the territory of Azerbaijan Republic. International Symposium on Modern Electric Power Systems (MEPS), 2010, pp. 1-4.

Gelfand A.E., Diggle P., Guttorp P. Fuentes M. Handbook of spatial statistics. CRC press. 2010, 619 p.

Haining R. Spatial data analysis: theory and practice. Cambridge University Press. UK, 2010, 432 p.

How Fuzzy Overlay works. ArcGIS for Desktop. ESRI. 2020, $288 \mathrm{p}$.

Kelsall J.E., Diggle P.J. Kernel estimation of relative risk. Bernoulli, Vol. 1, No. 1-2, 1995, pp. 3-16.

Koehler T.L. Cloud-to-ground lightning flash density and thunderstorm day distributions over the Contiguous United States derived from NLDN measurements: 1993-2018. Monthly Weather Review, Vol. 148, No.1, 2020, pp. 313-332.

Mackerras D., Darveniza M., Orville R.E., Williams E.R., Goodman S.J. Global lightning: total, cloud and ground flash estimates. Journal of Geophysical Research, Vol.103, No. 16, 1998, pp.19791-19809.

Mammadov R. Impact of climate changes on the Caspian Sea level. Journal of Resources and Ecology, Vol. 6, No. 2, 2015, pp. 87-92.

Mammadov R., Budagov B. The constructive geography of the Azerbaijan Republic. Elm. Baku, 1996, 245 p.

Mammadov R., Safarov S.G., Safarov E.S. Current changes of the atmospheric precipitation regime on the territory of Azerbaijan. Geography and Natural Resources, Vol. 30, No. 4, 2009, pp. 403-407.

NASA EOSDIS Global Hydrology Resource Center, GHRC User Services Office National Space Science and Technology Center, USA, 2013.

Ord J.K., Getis A. Local spatial autocorrelation statistics: distributional issues and an application. Geographical Analysis, Vol. 27, No. 4, 1995, pp. 286-306.

Peterson M., Deierling W. Liu C. Mach D., Kalb C. The properties of optical lightning flashes and the clouds they illuminate. J. Geophys. Res. Atmos., 2016, 121 p.

Rakov V.A. Fundamentals of lightning. Cambridge University Press. 2016, 257 p.

Rasouli A.A., Cheung K. Spatial distribution of severe thunderstorm rainfall events throughout the GMSTWA and adjacent the Tasman Sea. The $7^{\text {th }}$ Annual CAWCR Workshop, Observing, Estimating and Forecasting Rainfall: From Science to Application. 21-23 October 2013, Melbourne, Australia.

Rasouly A.A., Cheung K., McBurney B. Hail events across the Greater Metropolitan Severe Thunderstorm Warning Area. Natural Hazards Earth System Science, Vol.15, 2015, pp. 973-984.

Safarov S.H. The trend of changes in the frequency of hail in different regions of Azerbaijan. Proceedings of the Russian State Hydrometeorological University, St. Petersburg, 2008, No. 6, pp. 60-64 (in Russian).

Safarov S.H. Thunderstorms on the territory of Azerbaijan. Hydrometeorology and Ecology, Almaty, No. 3(46), 2007, pp. 44-54 (in Russian).

Safarov S.H., Mekhtieva G.Sh. The real situation with lightning on the territory of Azerbaijan. GESJ: Physics, No. 2(18), 2017, pp. 25-32 (in Russian).

Safarov S.H., Nasibli A.A., Huseynov J., İbrahimova İ.V. Influence of climate warming on hail events in the Western Part of Azerbaijan. Proceedings of International Scientific Conference on Sustainable Development Goals 24-25 November 2017, Baku, Azerbaijan, pp. 83-89.
Fischer M.M., Getis A. Handbook of applied spatial analysis software, tools, methods and applications. Springer-Verlag Berlin Heidelberg. 2010, 805 p.

Gashimov A.M., Khidirov F.L. Babayeva A.R. Strength of the lightning activity in the territory of Azerbaijan Republic. International Symposium on Modern Electric Power Systems (MEPS), 2010, pp.1-4.

Gelfand A.E., Diggle P., Guttorp P. Fuentes M. Handbook of spatial statistics. CRC press. 2010, 619 p.

Haining R. Spatial data analysis: theory and practice. Cambridge University Press. UK, 2010, 432 p.

How Fuzzy Overlay works. ArcGIS for Desktop. ESRI. 2020, $288 \mathrm{p}$.

Kelsall J.E., Diggle P.J. Kernel estimation of relative risk. Bernoulli, Vol. 1, No. 1-2, 1995, pp. 3-16.

Koehler T.L. Cloud-to-ground lightning flash density and thunderstorm day distributions over the Contiguous United States derived from NLDN measurements: 1993-2018. Monthly Weather Review, Vol. 148, No.1, 2020, pp. 313-332.

Mackerras D., Darveniza M., Orville R.E., Williams E.R., Goodman S.J. Global lightning: total, cloud and ground flash estimates. Journal of Geophysical Research, Vol.103, No. 16, 1998, pp.19791-19809.

Mammadov R. Impact of climate changes on the Caspian Sea level. Journal of Resources and Ecology, Vol. 6, No. 2, 2015, pp. 87-92.

Mammadov R., Budagov B. The constructive geography of the Azerbaijan Republic. Elm. Baku, 1996, 245 p.

Mammadov R., Safarov S.G., Safarov E.S. Current changes of the atmospheric precipitation regime on the territory of Azerbaijan. Geography and Natural Resources, Vol. 30, No. 4, 2009, pp. 403-407.

NASA EOSDIS Global Hydrology Resource Center, GHRC User Services Office National Space Science and Technology Center, USA, 2013.

Ord J.K., Getis A. Local spatial autocorrelation statistics: distributional issues and an application. Geographical Analysis, Vol. 27, No. 4, 1995, pp. 286-306.

Peterson M., Deierling W. Liu C. Mach D., Kalb C. The properties of optical lightning flashes and the clouds they illuminate. J. Geophys. Res. Atmos., 2016, 121 p.

Rakov V.A. Fundamentals of lightning. Cambridge University Press. 2016, 257 p.

Rasouli A.A., Cheung K. Spatial distribution of severe thunderstorm rainfall events throughout the GMSTWA and adjacent the Tasman Sea. The $7^{\text {th }}$ Annual CAWCR Workshop, Observing, Estimating and Forecasting Rainfall: From Science to Application. 21-23 October 2013, Melbourne, Australia.

Rasouly A.A., Cheung K., McBurney B. Hail events across the Greater Metropolitan Severe Thunderstorm Warning Area. Natural Hazards Earth System Science, Vol.15, 2015, pp. 973-984.

Safarov S.H., Nasibli A.A., Huseynov J., İbrahimova İ.V. Influence of climate warming on hail events in the Western Part of Azerbaijan. Proceedings of International Scientific Conference on Sustainable Development Goals 24-25 November 2017, Baku, Azerbaijan, pp. 83-89.

Scott L.M., Janikas M.V. Spatial statistics in ArcGIS. In: Fischer M.M., Getis A. (eds) Handbook of applied spatial analysis. Springer. Berlin, Heidelberg and New York, 2010, pp. 27-41.

Second national communication to the United Nations framework convention on climate change. Ministry of Ecology and Natural Resources. Baku, Republic of Azerbaijan, 2010, https://unfccc.int/sites/default/files/resource/Azerbaijan.

Understanding Spatial Statistics in ArcGIS. Vol. 1. ESRI Press. 2006, 312 p. 


\title{
Geography
}

Scott L.M., Janikas MV. Spatial statistics in ArcGIS. In: Fischer M.M., Getis A. (eds) Handbook of applied spatial analysis. Springer. Berlin, Heidelberg and New York, 2010, pp. 27-41.

Second national communication to the United Nations framework convention on climate change. Ministry of Ecology and Natural Resources. Baku, Republic of Azerbaijan, 2010, https://unfccc.int/sites/default/files/resource/Azerbaijan.

Understanding Spatial Statistics in ArcGIS. Vol. 1. ESRI Press. 2006, 312 p.

Wanke E., Andersen R., Volgnandt T. A Worldwide low-cost community-based time-of-arrival lightning detection and lightning location network. Blitzortung.org, 2014, 95 p.

Williams E.R. Lightning and climate: a review. Atmospheric Research, Vol. 76, 2005, pp. 272-287.

Yair Y., Shalev S., Erlich Z., Agrachov A., Katz E. Lightning flash multiplicity in eastern Mediterranean thunderstorms. Natural Hazards and Earth System Sciences, Vol. 14(2), 2014, pp. 165-173.

Zimmermann H.J. Fuzzy set theory and its applications. Fourth Edition. Kluwer Academic Publishers. Boston, Dordrecht, London, 2001, $441 \mathrm{p}$.
Wanke E., Andersen R., Volgnandt T. A Worldwide low-cost community-based time-of-arrival lightning detection and lightning location network. Blitzortung.org, 2014, 95 p.

Williams E.R. Lightning and climate: a review. Atmospheric Research, Vol. 76, 2005, pp. 272-287.

Yair Y., Shalev S., Erlich Z., Agrachov A., Katz E. Lightning flash multiplicity in eastern Mediterranean thunderstorms. Natural Hazards and Earth System Sciences, Vol. 14(2), 2014, pp. 165-173.

Zimmermann H.J. Fuzzy set theory and its applications. Fourth Edition. Kluwer Academic Publishers. Boston, Dordrecht, London, 2001, $441 \mathrm{p}$.

Сафаров С.Г. Грозовые явления на территории Азербайджана. Гидрометеорология и экология, Алматы, No. 3(46), 2007, c. 44-54.

Сафаров С.Г., Мехтиева Г.Ш. Реальное положение с молниями на территории Азербайджана. ГЭНЖ: Физика, No. 2(18), 2017, с. 25-32.

Сафаров С.Г. Тенденция изменения повторяемости града в различных регионах Азербайджана. Ученые записки РГМУ, Санкт- Петербург, 2008, No. 6, с. 60-64.

\section{ВИЗУАЛИЗАЦИЯ МОЛНИЕВЫХ ПРОЦЕССОВ НА ТЕРРИТОРИИ АЗЕРБАЙДЖАНСКОЙ РЕСПУБЛИКИ ПО ДАННЫМ С ДАТЧИКА ОТОБРАЖЕНИЙ МОЛНИЙ}

\author{
Мамедов Р.В. ${ }^{1}$, Расули А.А. ${ }^{2}$, Сафаров С. ${ }^{1}$, Сафаров . $^{1}$ \\ ${ }^{1}$ Институт Географии им. акад. Г.Алиева НАНА \\ AZ1070, г.Баку, nросп. Г.Джавида, 115 \\ ${ }^{2}$ Департамент наук об окружающей среде, Университет Маккуари, Сидней, Австралия \\ Австралия, Сидней, Нот Райд, Воллиз Вок,12, Уровень 4: aаrasuly@yahoo.com
}

\begin{abstract}
Для определения временной вариации и пространственного распределения ударов молний (вспышек) по районам Азербайджана были проанализированы имеющиеся данные о молниях, полученные с помощью датчика отображений грозовых разрядов. Каждая обнаруженная вспышка считается атмосферным событием. Почти 2074 вспышки за теплые и холодные месяцы с 2017 по 2020 год были объединены в четырехгодичную “сеть данных о молниях”, происходящих на территории грозоопасного региона с разрозненно расположенными в нем городами и селами с населением около 10 миллионов человек. ГИС методика целенаправленно применялась путем ввода данных всех проявлений молний для создания соответствующих четких цифровых слоев, необходимых для последующего пространственно-временного анализа. Был применен ряд методов обработки главным образом с целью анализа и картирования существующих пространственных закономерностей между слоями данных. Были установлены различные временные и пространственные закономерности, показывающие кластеры (группы) значений частоты молний и других параметров, статистически значимых для территории Азербайджана. В заключение для выявления областей с высокой вероятностью вспышек молнии при создании растрового банка данных был применен комбинированный нечеткий оператор на основе метода Кендалла (выходные слои плотности). В результате было установлено, что более $99 \%$ вспышек происходит в период с апреля по сентябрь с единичным пиком в июне и значительной грозовой активностью в летние месяцы, что подтверждает ярко выраженный дневной пик в регионе. Кроме того, пространственные индексы показали, что наиболее частые и энергичные вспышки молний происходят над западными и северными районами страны, в основном над возвышенными районами Карабаха и Кавказских гор, что указывает на районы повышен-
\end{abstract} ного риска.

Ключевые слова: Азербайджан, молния, временно-пространственные закономерности, карта опасности воздействия молний

\section{ILDIRIM SAYĞACLARINDAN ALINMIŞ MOLUMATLAR OSASINDA AZORBAYCAN RESPUBLİKASI ӘRAZISINDD İLDIRIMLARIN VIZUALLAŞDIRILMASI}

\author{
Məmmədov R.V. ${ }^{1}$, Rasuli A.A. ${ }^{2}$, Səfərov S. ${ }^{1}$, Səfərov E. ${ }^{1}$ \\ ${ }^{1}$ AMEA akad. H.Oliyev ad. Coğrafiya Institutu \\ AZ 1143, Bakı s., H.Cavid prosp., 115 \\ ${ }^{2}$ Otraf mühita dair elmlar departamenti, Makkuari Universiteti, Avstraliya, Sidney \\ Avstraliya, Sidney, Makkuari Universiteti, North Ryde, Wally's Walk, 12, səviyya 4: aarasuly@yahoo.com
}

\begin{abstract}
Xülasə. Azərbaycanın rayonlar üzrə ildııım zərbələrinin (işartılarının) zaman variasiyasının və məkanca paylanmasının müəyyən edilməsi üçün tufan boşalmaları sayğacının təsvirlərinin köməyi ilə ildırımlara dair alınmış mövcud məlumatlar təhlil edilmişdir. Aşkar edilən hər bir işartı atmosfer hadisəsi hesab olunur. 2017-2020-ci illərin ilıq və soyuq ayları üçün 2074 işartı dördillik "ildırımlara dair məlumatlar şəbəkəsi”"ndə birləşdirilmişdir. Bu işartılar təxminən 10 milyon əhalisi olan pərakəndə yerləşmiş şəhər və kəndlərlə tufan təhlükəli regionun ərazisində baş vermişdir. Növbəti məkan-zaman təhlili üçün lazımi müvafiq səlis rəqəmli təbəqələrin yaradılması üçün ildırımların bütün təzahürlərinin məlumatlarının daxil olunması yolu ilə klimatoloji istiqamətlənmiş GíS məqsədəuyğun şəkildə tətbiq edilmişdir
\end{abstract}


Məlumat təbəqələri arasında mövcud məkan qanunauyğunluqlarının, əsas etibarilə, təhlili və xəritələnməssi məqsədilə məkan statistikasının və analizinin tam bir sıra vasitələri tətbiq edilmişdir.

Azərbaycan ərazisi üçün statistik əhəmiyyət daşıyan ildırımların tezliyinin və digər göstəricilərin klasterlərini (qrupları) göstərən müxtəlif zaman və məkan qanunauyğunluqları müəyyən edilmişdir. Yekündə ildırım işartılarının ən yüksək ehtimallığına malik əraziləri aşkar etmək üçün məlumatlar bankı yaradılanda Kendall metodu (sıxlığın çıxış təbəqələri) əsasında kombinə edilmiş qeyri-səlis operator tətbiq edilmişdir. Nəticədə muəyyən olunmuşdur ki, işartıların 99\%-dən çoxu iyunda (yazda apreldən iyunadək) vahid pik olmaqla apreldən sentyabradək dövrdə baş verir. Mühüm tufan aktivliyi yay aylarında regionda kəskin fadə olunmuş gündüz piki ilə təsdiq olunur. Bundan əlavə, məkan indeksləri göstərir ki, ən tez-tez və ciddi ildırım işartıları ölkənin qərb və şimal rayonlarının üzərində, əsasən Qarabağın və Qafqaz dağlarının yuksək rayonları üzərində baç verir. Bu isə ölkə daxilində yüksək riskli rayonları göstərir.

Açar sözlor: Azərbaycan, LIS, GíS məlumat bazaları, məkan-zaman qanunauyğunluqları, ildırım təhlükəsi xəritəsi 